\title{
Pemetaan Pengetahuan Lokal Sunda dalam Koleksi di Museum Sri Baduga
}

\author{
Rizki Nurislaminingsih $^{1 *}$; Wina Erwina ${ }^{1}$; Asep Saeful Rohman ${ }^{1}$ \\ ${ }^{1}$ Program Studi Ilmu Perpustakaan, Fakultas Ilmu Komunikasi, Universitas Padjadjaran
}

"Korespondensi: rizkinurvega@gmail.com

\begin{abstract}
Artifacts at the Sri Baduga Museum hold a diversity of local knowledge about Sundanese culture. This is important to study because the people in Pasundan land have had great wisdom as a tribal identity for more than thousands of years. Although people continue to switch from generation to generation, this nobleness can still be excavated through their inheritance, one of which is through the museum of the West Java government, the Sri Baduga Museum. Thus various types of collections become physical evidence of the knowledge held by the public throughout Java-West. The purpose of this study is to map Sundanese local knowledge contained in the collections at the Sri Baduga Museum, therefore qualitative research with narrative strategies and data collection methods through the interpretation of agricultural documents in the museum. The results of this study indicate that community knowledge is divided into the ability to make traditional fabrics, livelihoods, urban planning, lighting tools, handicrafts, small industries, calendars, arts, children's games, as well as languages and scripts. This research is useful as a source of information for anyone who has an interest in researching local knowledge, especially the Sundanese. This grouping of knowledge can help referrals for further research or more in-depth research.
\end{abstract}

Keywords: sundanese local knowledge; collection; sri baduga museum; sundanese culture

\begin{abstract}
Abstrak
Artefak di Museum Sri Baduga menyimpan keragaman pengetahuan lokal tentang budaya Sunda. Hal ini menjadi penting untuk dikaji sebab masyarakat di tanah Pasundan memiliki kearifan yang agung sebagai identitas kesukuan selama ratusan hingga ribuan tahun lamanya. Meski masyarakat terus mengalami pergantian generasi, keluhuran tersebut masih dapat digali melalui benda-benda peninggalan mereka, salah satunya melalui museum bentukkan pemerintah Jawa-Barat, yakni Museum Sri Baduga. Dengan demikian aneka jenis koleksi menjadi bukti fisik akan pengetahuan yang dikuasai masyarakat di penjuru Jawa-Barat. Tujuan penelitian ini adalah memetakan pengetahuan lokal Sunda yang terdapat dalam koleksi di Museum Sri Baduga, oleh sebab itu digunakan penelitian kualitatif dengan strategi naratif serta metode pengumpulan data melalui interpretasi dokumen kebudayaan di museum tersebut. Hasil penelitian ini menunjukkan bahwa pengetahuan masyarakat terbagi dalam kemampuan membuat kain tradisional, mata pencaharian, tata kota, alat penerangan, kerajinan tangan, industri kecil pande besi, penanggalan, kesenian, permainan anak-anak, serta bahasa dan aksara. Penelitian ini bermanfaat sebagai sumber informasi bagi siapa saja yang memiliki minat utuk meneliti tentang pengetahuan lokal, khususnya di tatar Sunda. Pengelompokkan pengetahuan ini memudahkan pembaca dalam memilah pengetahuan apa saja yang dikuasai masyarakat Sunda sehingga bisa menjadi rujukan untuk penelitian selanjutnya atau penelitian sejenis yang lebih mendalam.
\end{abstract}

Kata Kunci: pengetahuan lokal sunda; koleksi; museum sri baduga; budaya sunda

\section{PENDAHULUAN}

Suku Sunda memiliki beragam hasil karya yang merupakan produk pengetahuan masyarakat sejak ratusan tahun silam. Hasil olah pikir tersebut merupakan refleksi aktivitas kehidupan seharihari penduduk di penjuru Jawa-Barat pada masa itu. Mereka piawai menciptakan benda yang berguna bagi kebutuhan dasar manusia, seperti sandang, pangan dan tempat tinggal. Mereka mampu membuat bahan pakaian dengan motif atau corak yang kini kita sebut dengan kain tradisional. Perlengkapan dan peralatan sederhana untuk mencari bahan memasak juga telah diciptakan. Kebutuhan akan tempat tinggal untuk hidup menetap dan bersosialisasi dengan orang lain menjadikan mereka ahli dalam menata pemukiman yang memudahkan berinteraksi dengan tetangga terdekat. Tidak hanya itu, pada beberapa karya mereka memasukkan unsur keyakinan dalam hati bahwa ada zat yang lebih tinggi kuasa-Nya di luar diri mereka. Keyakinan akan adanya bahaya sebagai hukuman dari zat Yang Maha Agung jika melanggar aturan adat menjadi pemantik diri 
menciptakan sistem penghitungan waktu. Kalender sederhana tersebut berisi pembagian waktu yang kita kenal dengan istilah hari atau bulan yang baik dan buruk. Serupa dengan keyakinan pada waktu kebaikan dan keburukan, beberapa karya masyarakat juga menyiratkan unsur filosofis yang syarat akan makna kehidupan.

Hal tersebut seperti yang dijelaskan dalam hasil penelitian Saleh, Soejadi dan Lasiyo (2013) bahwa kearifan lokal budaya Sunda terdapat dalam ide, aktivitas dan artefak yang senantiasa dijadikan tuntunan dalam hubungan dengan sesama, lingkungan dan Sang Maha Pencipta. Keluhuran masyarakat terlihat dalam perilaku, etika, keyakinan, hukum adat yang dipatuhi dalam rutinitas kehidupan. Nilai kebijaksanaan budaya Sunda terwakili dalam budaya tutur (carita, nasihat, pantun, uga, folklor) dan bukti tertulis seperti naskah (manuscript) Babad, Serat, serta Wawacan. Substansi kearifan lokal budaya Sunda adalah nilai kebaikan yang mengungkapkan pikiran, perasaan, dan pengetahuan. Seluruh yang dimiliki masyarakat merupakan perwujudan dari jati diri penduduk di tanah Parahiyangan.

Seiring berjalannya waktu, kebutuhan masyarakat semakin beragam. Hal ini memberikan pengaruh saat pembuatan produk budaya yang tidak lagi sebatas pada kegunaan, melainkan perlu menambahkan unsur seni dan hiburan. Berbagai jenis alat musik tradisional mereka ciptakan untuk melengkapi senandung lisan. Variasi jenis permainan dibuat untuk menfasilitasi kegiatan anak-anak agar masa kecil mereka semakin menyenangkan. Kebutuhan untuk menguasai pengetahuan tertentu membuat mereka terlatih untuk menciptakan karya tulis berupa ukiran huruf di atas lembaran lontar dan nipah. Naskah kuno ini menjadi bukti bahwa masyarakat Sunda ingin mencatat pengetahuan disuatu media agar dapat mereka baca kembali sehingga kelak mudah untuk dikuasai, baik oleh diri sendiri, orang lain maupun keturunannya.

Hal tersebut seperti yang diungkapkan oleh Soh dan Omar (2012) bahwa pengetahuan lokal merujuk pada kemampuan sekelompok individu, mengandung kebijaksanaan, kepercayaan dan ajaran-ajaran yang berlaku di komunitas tertentu. Secara umum, pengetahuan lokal diwariskan turun temurun dari generasi ke generasi melalui tradisi lisan. Pengetahuan lokal biasanya berupa folklor, cerita rakyat, legenda, ritual, nyanyian tradisional, dan hukum adat. Pengetahuan lokal merupakan gabungan dari keahlian, keterampilan, kemampuan yang bersumber dari orang tua, pemangku adat, dan sesepuh dari masyarakat lokal di wilayah tertentu secara berkelanjutan namun umumnya belum terdokumentasi. Kompleksitas pengetahuan lokal tersebut menjadi bukti kekayaan para pribumi disuatu tempat.

Namun demikian kenyataan minimnya jumlah benda hasil dokumentasi menjadi permasalahan tersendiri ketika peneliti ingin mengenal dan menggolongkan jenis pengetahuan pribumi. Keterbatasan waktu juga menjadi permasalahan tersendiri bagi peneliti untuk mencari benda bukti sejarah di setiap penduduk yang ada di seluruh penjuru Pasundan. Oleh sebab itu peneliti memutuskan untuk melakukan pemetaan koleksi yang merepresentasikan kecerdasan pribumi di Museum Sri Baduga. Hal ini didasarkan pada informasi yang tercantum pada website resmi Dinas Pariwisata dan Kebudayaan Jawa Barat (2019) bahwa museum yang dibangun oleh pemerintah propinsi tersebut menyimpan koleksi sejarah peribumi tanah pasundan sejak berabadabad lamanya. Ini berarti museum memiliki peran sebagai agen pelestari suatu kebudayaan dari masa lampau agar tetap dapat diingat oleh generasi saat ini. Fungsi museum sebagai lembaga penyimpan memori juga dijelaskan dalam penelitian Warren dan Matthews (2018) bahwa museum berperan sebagai lembaga penyimpan bukti kultural dan intelektual masyarakat pada zaman dahulu. Koleksi yang ada mengandung ingatan individu, masyarakat atau lembaga yang ada pada peradaban masa lampau. Semua itu merupakan warisan budaya sekaligus warisan kecerdasan dari leluhur.

Dengan demikian perlu diadakan pengklasifikasian koleksi sekaligus pemetaan pengetahuan lokal yang terkandung didalamnya sebab sejatinya pengetahuan lokal Sunda beserta bukti artefaknya merupakan salah satu wujud identitas etnis. Sebagaimana diketahui bersama bahwa 
umumnya artefak tersimpan di museum. Meski minim tulisan pengantar, peletakaan benda tertentu di sebuah museum menjadi isyarat bahwa benda tersebut merupakan produk budaya yang mengandung pengetahuan dari para pribumi untuk membuatnya. Oleh sebab itu maka tujuan penelitian ini adalah memetakan jenis pengetahuan lokal Sunda yang terekam dalam koleksi di Museum Sri Baduga.

\section{METODE PENELITIAN}

Penelitian ini bertujuan untuk mengelompokkan jenis pengetahuan lokal Sunda yang terepresentasi dalam koleksi di museum. Oleh sebab itu digunakan penelitian kualitatif dengan strategi naratif serta metode pengumpulan data melalui interpretasi dokumen kebudayaan yang tersimpan di Museum Sri Baduga. Menurut Denzin dan Lincoln (2009) kualitatif dengan strategi naratif memungkinkan peneliti untuk bisa menetapkan alur cerita, mengurai isi teks, menuangkan perspektif atau opini penulis. Alur cerita merupakan adegan yang dibentuk sekaligus membentuk konteks sosial budaya. Isi teks adalah pesan informasi. Opini penulis dapat bersumber dari penulis sebuah karya, pengarang buku atau peneliti itu sendiri.

Metode pengumpulan data pada penelitian ini dilakukan dengan interpretasi dokumen kebudayaan yang kemudian diperkuat dengan hasil tulisan orang lain (jurnal atau buku) yang mendukung tema penelitian. Denzin dan Lincoln (2009) berpendapat, catatan lapangan, foto, "memory box", artefak dan dokumen lainnya yang diperoleh ketika peneliti melakukan kunjungan lapangan masuk dalam kategori data penelitian. Catatan lapangan dibuat oleh peneliti untuk menuangkan semua hal yang didapat ketika berada di lapangan sedangkan foto berisi rekaman peristiwa. "Memory box" adalah benda yang berisi perjalanan hidup, seperti hadiah, barang-barang yang diciptakan seseorang pada masa lalu, dan lain sebagainya. Semua itu mewakili kejadian, waktu dan identitas pembuatnya.

Pada penelitian ini data diperoleh dengan cara mengelompokan jenis benda atau artefak, menulis ulang apa yang ada dalam kertas informasi (penjelasan singkat tentang koleksi) yang terpajang di samping koleksi, menaratifkan setting peristiwa dalam diorama, serta mengutip literatur yang sesuai. Semua data disajikan dalam bentuk naratif sehingga memudahkan pembaca memahami pengetahuan yang terkandung dalam artefak di museum.

\section{HASIL DAN PEMBAHASAN}

Sesuai dengan fungsi utamanya, Museum Sri Baduga didirikan untuk mengumpulkan benda sejarah masyarakat Sunda. Jika ditelisik lebih dalam, koleksi museum sesungguhnya tidak hanya sebatas artefak yang dipajang. Pada benda tersebut terdapat informasi tentang kepiawaian pembuatnya. Ini berarti setiap benda mengandung pengetahuan dari masyarakat di seluruh tatar Sunda, baik itu tentang cara pembuatan benda, kegunaannya dan cara memanfaatkannya. Semua itu perlu dipetakan untuk memudahkan memahami pengetahuan lokal masyarakat Sunda.

Pendapat serupa diutarakan oleh Okorafor (2010) pengetahuan lokal merupakan solusi dasar bagi permasalahan tentang pertanian, kesehatan, makanan, kesenian, kerajinan, dan sumber alam yang dapat dimanfaatkan untuk kelangsungan hidup bagi komunitas tertentu. Pengetahuan lokal tidak dimiliki oleh perorangan, melainkan milik keluarga besar atau komunitas tertentu diaplikasikan dalam rutinitas, bersifat dinamis dan murni merupakan keahlian pribumi yang menggambarkan keselarasan hidup dengan lingkungan sekitar tempat tinggal.

Hal tersebut juga berlaku pada pengetahuan lokal pribumi Sunda, termasuk yang terepresentasi dalam koleksi di Museum Sri Baduga. Berikut hasil pemetaan pengetahuan lokal yang terkandung dalam koleksi yang telah penulis uraikan dalam bentuk naratif dan telah diperkuat dengan beberapa hasil penelitian lain. Pengetahuan tentang pembuatan batik dan tenun menjadi sebuah keahlian tentang kain tradisional. Keterampilan dalam mencari nafkah terepresentasi dengan 
kemampuan menciptakan peralatan untuk bekerja di sawah, ladang atau sungai dan laut. Masyarakat Sunda kuno juga piawai dalam menata pemukiman yang nyaman untuk dihuni, termasuk pembuatan alat penerang sebagai tambahan cahaya di sebuah tempat tinggal. Kerajinan anyaman, gerabah dan pande besi yang berkembang pesat pada masa lampau menggambarkan keahlian masyarakat pada penciptaan perabotan rumah tangga. Tidak hanya mahir dalam menciptakan peralatan, masyarakat juga ahli dalam membuat Kalender Sunda yang berguna sebagai panduan dalam beberapa aktivitas, tidak hanya sebatas pada perhitungan hari.

Seiring berjalannya waktu, kebutuhan masyarakat semakin beragam tidak sebatas pada pembuatan perlengkapan yang memudahkan gerak raga. Mereka menciptakan bermacam alat kesenian untuk mengisi kebutuhan jiwa akan keindahan dan kedamaian fikiran. Tidak hanya seni, merekapun mengerti kebutuhan jiwa anak-anak yang masih dalam tahap pertumbuhan. Perkembangan karakter anak-anak yang notabene harus bermain bersama teman sebagai dasar pembentukan jiwa sosial menjadikan penduduk tanah pasundan terampil membuat permainan tradisional. Perkembangan kemampuan masyarakat Sunda selanjutnya adalah kemampuan menulis. Mereka membuat Aksara Sunda yang sangat berguna untuk menuangkan keahlian, keterampilan, kepandaian yang kelak dapat dibaca oleh keturunan, sehingga anak-anak dapat mempelajari semua pengetahuan yang dikuasai oleh nenek moyang mereka.

\section{Batik dan Tenun}

Pembelajaran tentang batik khas pasundan didapat dari koleksi yang ditata menyerupai kegiatan membatik tulis. Miniatur alat, contoh kain tradisional, patung pengrajin dan kertas panduan pembuatan memberi gambaran pada pengunjung tentang cara membatik secara tradisional. Dari koleksi yang dipajang tersebut kita juga dapat memahami bahwa pewarna kain tradisional terbuat dari kayu soga dan daun indigo. Selain itu, kita bisa mengenali asal daerah batik berdasarkan coraknya, sebab masing-masing daerah di Jawa Barat memiliki ciri yang menjadi pembeda. Batik dari Cirebon dikenal Cirebonan dengan motif guci. Indramayu merupakan penghasil batik Dermayon dengan ukiran berbentuk iwak entong. Warga Garut menghasilkan Garutan dengan dua gambar yang menjadi andalan, Merak Ngibing dan Rereng Apel. Batik Tasik menjadi Tasikan dengan motif Puger Galing. Batik Ciamisan motif Rereng Sirau menjadi salah satu produk lokal kebanggaan kota Ciamis.

Penjelasan tambahan tentang batik Sunda terdapat dalam penelitian Sunarya (2018) bahwa sesungguhnya latar belakang masyarakat mempengaruhi hias batik khas Parahiyangan. Kawasan tempat tinggal di pegunungan mempengaruhi corak batik bertema agraria, contohnya Bango Rawa, Manggu (buah manggis), Kakembangan (jenis bunga-bungaan), Kopi, Kukupu (kupu-kupu), Daun Sampeu (daun singkong), Daun Taleus (daun talas), Kurung Hayam (kurungan ayam), Batu, Bilik, Merak, Lancah, Awi (ruas bambu), Kembang Tahu, dan Batuhiu. Intinya, apapun yang mereka lihat dalam kehidupan sehari-hari, baik itu di sawah, ladang, rawa, atau kolam dapat menjadi sumber inspirasi yang memperkaya jenis hiasan di kain batik.

Diorama kegiatan menenun juga dipajang di museum Sri Baduga, lengkap dengan miniatur alat dan selembar kertas yang bertuliskan cara menenun. Tenun menjadi kerajian kain lainnya yang memperkaya jiwa seni wanita Sunda dalam memintal benang menjadi lembaran kain yang indah. Sumedang, Garut, Majalaya dan kabupaten Bandung tercatat menjadi tempat yang memproduksi tenun berkualitas. Penduduk di daerah tersebut mengetahui bahwa benang yang terbuat dari ulat sutra dapat dibuat menjadi kain tenun yang bermutu tinggi. Dari diorama tersebut kita bisa mengenal bentuk, nama alat dan proses pembuatan kain tenun secara tradisional. 


\section{Mata Pencaharian}

Pengetahuan tentang mata pencaharian dapat dilihat dalam penggolongan koleksi alat pertanian, perkebunan dan perikanan. Pergantian zaman merubah pola hidup berburu dan meramu menjadi mengolah lahan. Kegiatan ini diawali dengan membuka hutan, memotong semak belukar, membersihkan rumput dan menebang pohon dan mengolah tanah agar cocok untuk bertani dan berkebun. Merekapun menciptakan alat yang berbeda untuk memotong dan menebang pohon. Belukar dibersihkan menggunakan Congkrak sedangkan Golok digunakan untuk merobohkan pohon.

Masyarakat yang bekerja sebagai petani memanfaatkan kerbau untuk membajak sawah. Mereka menyadari bahwa tumbuhan padi tidak cocok ditanam pada tanah keras layaknya palawija. Tanah yang tadinya keras menjadi lebih lunak setelah diinjak oleh kerbau berkali-kali. Setelah itu digunakan Singkal dan Pacul untuk membolak-balikkan tanah agar gembur. Tanah tersebut kemudian diberi lubang untuk menanam bibit padi dengan menggunakan alat bernama Aseuk atau Tugal. Agar padi tumbuh berurutan dan rapi maka digunakan Caplak untuk mengatur jarak yang sama. Barisan pohon padi yang rapi memudahkan petani ketika memanen. Pengetahuan masyarakat akan pertanian semakin berkembang ketika menyadari rumput yang tumbuh disekitar padi akan menyerap nutrisi tanah yang dibutuhkan padi. Jika tidak disiangi maka padi tidak akan tumbuh sempurna. Maka diciptakan Lalandakan dan Kukuyaan untuk membersihkan tanaman liar di sekitar padi.

Selain bertani, masyarakat pun piawai dalam berkebun. Mereka telah mengenali cara menanam palawija. Mereka juga mampu menciptakan alat yang berbeda untuk membersihkan tumbuhan di kebun. Kored untuk menyiangi rumput disekitar tumbuhan palawija dan untuk membersihkan tanaman pengganggu di pinggir ladang mereka menggunakan Parang atau Congkrak. Kebutuhan tanaman kebun akan air membuat masyarakat menciptakan alat tradisional untuk menyiram palawija. Bambu muda didesain sedemikian rupa agar membentuk wadah untuk menampung air dan menyiram tanaman, sehingga dinamakan Timba Pring. Jika disamakan dengan peralataan saat ini, fungsi wadah tersebut serupa dengan ember untuk menimba air dari sumur.

Dari koleksi peralatan juga dapat diketahui bahwa kegiatan menangkap ikan secara garis besar dilakukan melalui tiga cara, yakni memasang perangkap, merungkup dan menciduk. Alat jebakan ikan bernama Bubu, Joged dan Impes. Kecrik dan Susug sebagai perungkup dan ketika ingin mengambil ikan yang telah terkumpul melalui alat perangkap atau perungkup maka digunakan Sirib. Terakhir, hasil tangkapan disimpan dalam bernama Cireung dan Buleng. Jika nelayan ingin menjajakan hasil melaut untuk dijual keliling kampung, maka ikan dipindahkan ke wadah bernama Naya.

Diluar pengetahuan yang terekam dalam koleksi di museum, masyarakat Sunda sesungguhnya memiliki pengetahuan untuk menyeimbangkan mata pencaharian dengan alam. Misalnya dalam hal bertani, zaman dahulu biasanya masyarakat mengadakan ritual khusus, perhitungan tertentu tentang waktu musim tanam atau panen dan pemilihan peralatan tententu, yang semua itu diniatkan untuk menjaga eksistensi lingkungan. Bahasa mudahnya, ritual merupakan tindakan tertentu yang tidak sekedar memanfaatkan hasil bumi, tetapi juga harus diimbangi dengan tindakan melestarikan alam. Perhitungan waktu tanam dan panen pun dirancang untuk memberi jarak waktu pada alam agar dapat menumbuhkan tanaman yang tidak habis sekali panen. Mereka percaya bahwa tumbuhan di hutan berguna sebagai pelindung diri atau sumber hidup yang sehat. Peralatan tertentu digunakan agar tidak merusak tanah dan tumbuhan (Indrawardana, 2012).

\section{Tata Kota}

Kampung Naga di daerah Neglasari Tasikmalaya menjadi bukti kepiawaian penduduk Pasundan dalam bidang tata kota. Dilihat dari gambar denah, kampung tradisional tersebut masih 
menerapkan prinsip penggunaan fasilitas umum demi kepentingan bersama. Tempat ibadah, pendopo untuk pertemuan warga dan alun-alun diposisikan di tengah kampung, sehingga memudahkan seluruh warga untuk berkumpul. Kampung tersebut juga memiliki lumbung padi bersama yang dibuat khusus untuk mencegah kekurangan beras ketika musim paceklik. Kandang ternak dan toilet di bangun agak berjauhan dari rumah dengan pertimbangan agar baunya tidak mengganggu kesehatan warga. Posisi perumahan yang dibangun dekat dengan sungai memudahkan masyarakat dalam mencari ikan, mengairi sawah dan untuk memenuhi kebutuhan lainnya yang memerlukan air.

Penjelasan lebih lengkap tentang Kampung Naga dapat diketahui dalam penelitian Wiradimadja (2018), bahwa masyarakat di wilayah tersebut hingga kini masih menjaga kearifan lokal untuk terus melakukan konservasi lingkungan dalam kehidupan sehari-hari. Warga kampung hidup selaras dengan alam yang dibuktikan dengan adanya pembagian lingkungan dalam tiga hal, wilayah bersih (untuk memukiman dan aktivitas bersama), wilayah kotor dan hutan larangan. Wilayah bersih ditata agar warga dapat menghirup udara bersih dan beraktivitas di atas tanah yang sehat, tanpa terganggu dengan kotoran ternak. Wilayah kotor dikhususkan untuk memelihara hewan ternak dan aktivitas MCK penduduk, sehingga semua kotoran terkumpul pada satu area. Hutan larangan berguna untuk membatasi pembabatan hutan, perburuan hewan liar dan melarang beragam aktivitas yang tidak perlu dilakukan. Hal ini merupakan usaha untuk menjaga kelangsungan hidup tumbuhan yang merupakan sumber oksigen bagi penduduk sekitar.

Berdasarkan penjelasan tersebut dapat dipahami bahwa penduduk Kampung Naga menguasai pengetahuan tentang tata kota yang bersih dan sehat yang diaplikasikan melalui peraturan adat setempat. Pengetahuan masyarakat di Kampung Naga tidak hanya sebatas pada pengaturan posisi tempat tinggal, mereka mengerti cara membangun rumah di tepi tebing namun tahan gempa dengan pondasi tanpa semen. Mereka juga memahami pentingnya ventilasi agar penghuni rumah dapat menghirup udara segar setiap saat. Pengetahun lain yang mereka miliki adalah meracik tumbuhan agar menjadi kosmetik alami yang berguna sebagai sabun mandi, sampo dan pasta gigi (Wiradimadja, 2018).

\section{Alat Penerangan}

Kekayaan pengetahuan warga Jawa Barat tentang api juga tercatat di museum. Mereka piawai memilih jenis batu yang bisa menghasilkan api, yakni batu besi. Masyarakat Baduy menyebut pemantik api tersebut Paneker sedangkan di Priangan bernama Gandawesi. Ribuan tahun lalu masyarakat telah mengenal teknik membuat api dengan cara membenturkan atau menggosok dua bilah batu tepat diatas rumput atau ranting kering. Percikan api yang terkumpul akan membakar daun dan ranting. Setelah api tercipta, mereka menambahkan kayu kering untuk membuat bara. Kemudian, bara dikumpulkan dan ditampung dalam bulu batang pohon aren, masyarakat setempat menyebutnya Awul. Sejalan dengan perkembangan zaman, mereka mampu membuat bahan bakar dari lemak hewan dan tumbuhan. Merekapun membuat wadah penampung berbentuk piringan yang bernama Pelita.

Kemampuan masyarakat dalam membuat wadah penampung bahan bakar kian beragam. Masing-masing penjuru tanah pasundan memiliki kekhasan bentuk dan bahan pembuatan yang berbeda. Bandung mengenal Lampu Tempel Berukir dengan bahan kuningan. Sandaran lampu untuk dikaitkan di dinding terbuat dari kayu yang di ukir. Banten memiliki Lampu Pangawang yang terbuat dari bambu. Sumbu untuk menghidupkan pangawang ditetakkan dalam mangkuk kecil yang terbuat dari batu. Cirebon menjadi tempat yang memiliki jenis lampu terbanyak beserta keragaman penggunaanya. Pihak kerajaan menggunakan lentera kebesaran bernama Cupu Manik yang terbuat dari logam dan kaca untuk penerang kirab Sultan Kasepuhan Cirebon. Ajug, yakni lampu sederhana yang terbuat dari batu sering dimanfaatkan rakyat biasa untuk penerang surau. Jika ada kegiatan 
pementasan wayang kulit masyarakat memilih menggunakan Lampu Delapak motif wayang yang terbuat dari kayu.

\section{Kerajinan Anyaman dan Gerabah}

Bagi masyarakat Sunda, anyaman tidak semata menjadi tambahan mata pencaharian selain bertani, berkebun atau menangkap ikan. Bahan anyaman seperti bambu memiliki makna filosofis sebagai lambang kekuatan. Bahan lain, yakni pandan mewakili makna lentur, halus dan karakter yang mudah dibentuk. Produk anyaman berupa tikar misalnya, benda yang lazim digunakan sebagai alas tersebut memiliki arti khusus dalam kehidupan. Masyarakat lahir di atas tikar, duduk dan berkumpul dengan rekan dan saudara di atas tikar, bahkan meninggal juga di tutup dengan tikar. Masyarakat membuat anyaman untuk keperluan rumah tangga, seperti Aseupan (pengukus nasi), Besek (wadah untuk hantaran), Hihid (kipas) dan Keranjang. Ciamis, Garut, Majalengka dan Tasikmalaya merupakan daerah pengrajin anyaman yang sudah dilaksanakan turun-temurun sejak nenek moyang.

Penjelasan lebih lengkap tentang anyaman khas Priangan terdapat dalam penelitian Sofyan dkk (2018), bahwa warga Tasikmalaya secara turun temurun mengajarkan pengetahuan tentang anyaman kepada generasi yang lebih muda. Produk yang dibuatpun lebih bervariasi, seperti dompet tembakau, sandal, topi untuk ke ladang, tas, kap lampu, bakul, kursi dan asesoris untuk cindera mata. Tidak hanya mengutamakan unsur kegunaan, kerajian dari bambu tersebut mulai dihiasi dengan berbagai motif seperti Kepang Dua, Yarbes, Mata Itik, Kembang Buhun, Joher, Katuncar Mawur dan Bunga Sakura. Bahkan seni anyaman kini mulai dikembangkan untuk menjadi destinasi wisata ikonik Kerajinan Tangan di Tasikmalaya. Selain pembahasan tentang jenis produk anyaman, pada penelitian Sofyan dkk (2018) juga tergambar pengetahuan warga tentang proses pembuatannya. Para pengrajin mengetahui bahwa tidak semua jenis bambu dapat dibuat kerajinan. Mereka hanya memilih Bambu Apus untuk dibuat menjadi bahan utama anyaman, sebagai pelengkap mereka menggunakan Bambu Ori. Pemilihan jenis bambu tersebut didasarkan pada pengalaman penggunaan berbagai jenis bambu. Mereka percaya bahwa jenis Apus memiliki kualitas paling baik, sehingga produk yang dihasilkan tidak mudah rusak.

Ragam kerajinan tangan masyarakat Jawa-Barat diperkaya dengan adanya Gerabah. Mereka mengenal teknik membuat wadah dari tanah liat sejak zaman prasejarah. Cara paling sederhana dimulai dengan memukul sebongkah tanah dengan kayu atau bambu untuk membentuk wadah tertentu, lalu di bakar agar kering. Perkembangan teknik mengolah tanah liat selanjutnya adalah teknik putar dan mulai memberi ukiran untuk menambah keindahan wadah. Mereka telah menguasai pengetahuan untuk menggambar di permukaan tanah basah, yakni menggunakan benda runcing dan tali. Duri ikan digunakan untuk menggukir sedangkan tali yang ditekan di tanah basah untuk memberikan efek cekungan. Sadang Gentong dan Babakan Pariuk (Garut), Lelean (Indramayu), Ciruas (Banten), dan Kampung Anjun (Purwakarta) tercatat sebagai daerah penghasil gerabah terbaik di Jawa-Barat.

\section{Industri Kecil Pande Besi}

Teknologi pengolahan logam secara tradisional telah dikuasai warga Serang, Sukabumi, Bandung, Garut, Sumedang dan Kuningan dengan cara mendirikan pande besi meski dengan peralatan sederhana. Tungku tanah liat difungsikan sebagai pemanas api untuk meleburkan bongkahan besi. Jika sudah memanas seperti bara, bongkahan di pukul-pukul dengan palu besar hingga pipih. Lempengan besi kemudian di potong dan ditempa berulang kali untuk membentuk benda yang diinginkan. Jika sudah berbentuk maka bagian ujung atau tepi diruncingkan atau ditajamkan menggunakan Kikir. Setelah itu benda tersebut bisa digunakan sebagai Pisau, Golok, Kored, dan peralatan pertukangan lainnya. 
Meski hingga saat ini pande besi masih bisa ditemukan di beberapa wilayah Jawa-Barat, kerajian tersebut tergolong sudah semakin langka. Sebagai contoh, pande besi di Cimaragas Garut. Dari tulisan Supriadin (2019) di situs berita online yakni liputan6.com dapat diketahui bahwa pesanan peralatan di pande besi semakin menurun seiring menjamurnya produk pabrikan modern. Produk alat pertukangan tradisional seperti pisau, kored, cangkul, arit atau congkrak khas JawaBarat mulai sepi peminat. Masyarakat lebih memilih peralatan dengan fungsi serupa namun buatan Cina, sebab memiliki harga yang lebih murah. Berdasarkan kenyataan tersebut, terdapat kemungkinan pada suatu saat nanti pengetahuan tentang menempa besi secara manual akan hilang dari ingatan penduduk. Dengan demikian, keahlian tentang membuat peralatan berbahan besi hanya dapat diketahui melalui benda koleksi museum.

\section{Kalender Tradisional}

Penduduk di Baduy di Lebak telah mengenal penanggalan tradisional yang bernama Sastra. Perhitungan waktu diukir di bambu dengan teknik menggores. Sastra digunakan untuk menentukan hari baik pernikahan, waktu bercocok tanam dan aktivitas mencari nafkah lainnya. Serupa fungsi dengan Sastra, suku Baduy juga penanggalan lain yang berguna untuk menentukan hari baik dan buruk namun ditulis di lembaran papan kayu, bernama Kolenjer dan Tunduk.

Uraian singkat tentang penanggalan Sunda dituliskan oleh Jubaedah (2018) pada surat kabar lokal online. Mengutip ungkapan perwakilan Dewan Pembina Bestdaya, wartawan Tribun Jabar tersebut menuliskan bahwa kalender Sunda memiliki tiga perhitungan, yaitu Panon Poe (matahari), Candra (bulan) dan Sukra (Bentang). Panon Poe untuk menentukan musim, Candra untuk menuliskan sejarah serta administrasi aktivitas sehari-hari, sedangkan Sukra berguna untuk kegiatan pelayaran atau menangkap ikan.

Pemanfaatan kalender tradisional Sunda dalam sistem mata pencaharian diterapkan oleh suku Baduy. Mereka menerapkan larangan untuk bekerja di ladang setiap tanggal 15 dan 30 menurut perhitungan kalender suku. Bulan Kanem dipercaya sebagai masa paceklik. Bulan Kasa, Karo, dan Katiga, yang merupakan bulan-bulan akhir masa berladang dan masa panen disebut pula masa Kawalu. Pembagian masa tanam, panen dan larangan mengunjungi ladang secara perlahan tapi pasti menjadi salah satu cara masyarakat untuk memberikan waktu pada alam untuk berevolusi, terutama untuk membentuk kesuburan tanah dan pertumbuhan tanaman secara alami (Ipa dkk, 2014).

\section{Kesenian}

Masyarakat Cirebon telah mengenal seni menggambar di permukaan kaca sejak abad 17. Secara garis besar teknik melukis diawali dengan membuat sketsa pada kertas, kemudian ditempel pada kaca. Pelukis lalu menggambar di sisi kaca lainnya (sebaliknya). Gambar sesuai dengan sketsa. Pada saat itu lukisan kaca digunakan sebagai media dakwah agama Islam. Gambar lukisan yang sebagian besar berupa kaligrafi atau wayang merupakan representasi makna kitab suci. Seiring berjalannya waktu, tercatat sejak abad 19, lukisan yang terukir di kaca mengalami perkembangan motif, seperti Batik Mega Mendung, Paksi Naga Liman dan Singa Barong.

Pengetahuan masyarakat dalam menciptakan aneka nada dapat diketahui dari keragaman perkusi tradisional. Mereka menyadari perbedaan bahan pembuatan dan cara memainkan akan menghasilkan suara yang berbeda. Keterampilan jemari dalam menggerakan susunan bambu hingga membentuk irama terlihat dalam lestarinya penggunaan Angklung Buhun dan Angklung Gubrak hingga saat ini. Lincahnya jari masyarakat juga terlihat dari eksisnya alat musik yang dimainkan lewat petikan senar, yakni Kacapi Siter, Kacapi Rincik dan Kacapi Indung. Umumnya kecapi menghasilkan suara denting. Terompet, Karinding, Taleot dan Suling menjadi bukti kemahiran masyarakat memainkan alat musik tradisional melalui teknik meniup. Pukulan lembut pada 
Celempung Kayu dan Celempung Bambu akan menghasilkan tiruan suara aliran air yang tenang. Rebab, yang sepintas bentuknya menyerupai biola digunakan oleh pemusik untuk menciptakan suara yang menyiratkan kesedihan. Efek dentuman diperoleh dari Goong.

Pada zaman dahulu, pemanfaatan instrument Angklung tidak semata untuk menciptakan suara (musik) untuk hiburan masyarakat. Penduduk Parahiyangan percaya bahwa Angklung menjadi media penyeimbang kosmologi "dunia atas" dengan "dunia bawah". Dunia atas merujuk pada kehidupan kayangan, tempat bersemayamnya dewa dan dewi sedangkan dunia bawah merupakan kehidupan umat manusia di bumi. Permainan Angklung menjadi sajian ritual musikal untuk Dewi Padi atau Dewi Sri. Nyi Pohaci Sanghyang Sri, yakni Dewi Padi versi Sunda dikisahkan sebagai sosok yang menjaga padi. Persembahan suara Angkung diyakini sebagai bentuk membahagiakan hati sang dewi agar kelak memberikan kesuburan pada hasil panen. Serupa dengan pemanfaatan Angklung sebagai sarana persembahan musik bagi "penguasa padi", masyarakat Sunda lainnya khususnya di Banten Selatan (Kanekes) memasang Calitu dan Kolecer sebagai alat yang akan menghasilkan suara merdu jika tertiup angin. Hal ini ditujukan untuk menghibur dan menemani Dewi Sri agar hatinya bahagia saat menunggu sawah, sehingga padi tumbuh subur dan panen melimpah (Nugraha, 2015).

\section{Permainan Tradisional}

Diorama berisi aneka benda-benda yang sering digunakan sebagai sarana bermain juga menyimpan pengetahuan akan kreativitas anak-anak zaman dahulu. Mereka bisa membuat tiruan telepon, alat tembak, burung, kincir angin dan mobil menggunakan bahan dari alam atau dari benda tak terpakai di rumah. Teteleponan terbuat dari dua kaleng susu bekas yang disatukan dengan seutas benang digunakan untuk berkomunikasi oleh dua anak, seolah sedang berbicara menggunakan telepon. Bedil Jepret dan Pepeletokan menjadi senjata tradisional dari bambu untuk bermain peran layaknya tentara yang ahli menembak. Butiran sayuran leunca atau jambu air yang masih sangat kecil menjadi peluru. Mamanukan terbuat dari tanah liat yang dibentuk menyerupai burung dan diberi beberapa lubang. Setelah kering, maka menjadi mainan dengan cara ditiup di bagian ekornya, kemudian akan terdengar suara mirip kicau burung. Kolecer dibuat dari lipatan kertas warna-warni yang dirangkai di sebilah bambu. Anak-anak harus berlari mengejar angin agar Kolecer dapat berputar layaknya kincir. Momobilan terbuat dari triplek, bambu, kayu, kaleng bekas atau kulit jeruk yang dirangkai membentuk mobil.

Beberapa contoh koleksi yang dipajang di Museum Sri Baduga sampai saat ini masih dimainkan oleh anak-anak di beberapa daerah di Jawa-Barat, seperti di Kabupaten Bandung. Suparman, dkk (2018) menuliskan permaian khas Jawa-Barat yang masih lestari di wilayah tersebut, lengkap dengan varian nama lainnya (sebutan lainnya untuk nama permainan yang sama) yang dikenal oleh anak-anak, seperti Ucing Sumput (Ucing Pengungpeun), Boy-boyan (Ucing Baledog), Oray-orayan (Kakaretaapian), Sondah (Engkle), Kaleci (Rarajaan), Kelereng, Jajangkungan, Loncat tinggi, Congkak (Congklak), Kewuk (Kuwuk atau Beklen), Gagarudaan, Ular Tangga, Dam-daman, Gatrik, Hompimpa, Ngadu muncang, Perepet jengkol, Benteng, Kobak, Gasing, Perepet Jengkol, Katapel, Sorodot Gaplok, Rorodaan, Kelom Batok, Bedil Jepret, dan Anjang-anjangan.

Tidak hanya terampil dalam menciptakan media bermain, anak-anak juga ahli dalam menguasai permainan yang membutuhkan pengetahuan khusus. Sebagai contoh permainan Egrang dan Kelom Batok, mereka harus belajar teknik keseimbangan badan agar tidak jatuh saat melangkah. Permainan lain yang menuntut konsentrasi adalah Dam-daman. Mainan yang dijalankan dengan teknik mirip catur tersebut membutuhkan kecerdasan dan tak-tik agar tidak kalah ketika bertanding. 
Pentingnya menjaga kelestarian mainan tradisional khas Sunda diutarakan oleh Gubernur Jawa-Barat dan Ketua Lembaga Perlindungan Anak Indonesia. Hal ini dapat diketahui dalam website resmi Pemerintah Kota Bogor (2019), bahwa pimpinan Jawa-Barat kian gencar memberikan kampanye Astaga (Asik Tanpa Gawai) sebagai perwujudan peduli pada kelestarian permainan tradisional. Ridwan Kamil sebagai Gubernur berpendapat bahwa kegembiraan anakanak menikmati mainan khas daerahnya tanpa ketergantungan dengan teknologi merupakan cerminan adiluhung peradaban di tatar Jabar. Nilai positif permainan tradisional diungkapkan oleh Kak Seto selaku ketua yayasan pemerhati anak, bahwa berperan sebagai stimulus psikomotorik, psikososial, pembangun nilai moral dan melatih kejujuran.

\section{Bahasa dan Aksara}

Kepandaian penduduk akan tulis-menulis tumbuh sejak abad 5 masehi, tepatnya saat pemerintahan Tarumanegara. Tulisan tersebut diukir guna menuangkan apa saja yang diketahui dan dianggap sangat penting pada masa itu. Kesadaran masyarakat akan pentingnya menjaga pengetahuan terlihat pada variasi isi manuskrip yang ditemukan di penjuru Jawa-Barat. Tradisi tutur yang menceritakan berbagai kisah (peristiwa sejarah maupun tokoh penting) perlahan mulai dibukukan. Begitu pula dengan ajaran leluhur yang menjadi dasar hidup masyarakat. Semua itu dituliskan dalam kertas dan dijilid, kini kita menyebutnya naskah kuno, yang tertua berasal dari abad 15 hingga 16 masehi dengan bahan Daun Lontar dan Nipah. Setelah era tersebut, masyarakat mengenal bahan lain yang dapat menjadi media tulis, seperti kertas Daluang dan Saeh.

Kepercayaan terhadap agama tertentu turut mewarnai pengetahuan yang tersimpan dalam naskah yang menjadi koleksi museum. Contohnya tentang Riwayat Nabi Muhammad tertulis lengkap di tiap lembar kertas, mulai dari kelahiran, masa kecil, dewasa, hingga menjadi nabi. Kisah yang berbentuk puisi tersebut di tulis di atas kertas saeh sekitar abad 19. Manjalengka menjadi tempat penyimpanan terakhir manuskrip sebelum dimuseumkan. Dari Ciamis didapat satu naskah yang berisi tuntunan hidup masyarakat Sunda, yakni Nitisruti. Moralitas, tatakrama, hukum, filsafat dan kesusastraan yang menjadi ajaran hidup tertulis lengkap didalamnya. Cirebon memiliki kisah peristiwa sejarah yang dikenal dengan Naskah Babad Banten dan Naskah Balbuhak Babad Cirebon.

Asal usul aksara Sunda dapat ditelusuri dari penulisan prasasti dan piagam zaman kerajaan di bumi Pasundan. Tulisan tertua ada pada prasasti Kawali abad XIV dan termuda ada pada Naskah Waruga Guru pada akhir abad 18. Eksistensi aksara Sunda Kuno selama ratusan tahun ini menunjukkan pengetahuan masyarakat yang mumpuni. Meski sempat vakum beberapa saat, di era modern seperti saat ini, geliat untuk menggunakan aksara Sunda kembali muncul di diri masyarakat. Beberapa nama jalan, gapura suatu wilayah, nama kantor pemerintahan dan baliho raksasa di JawaBarat kerap menambahkan aksara Sunda sebagai kata lain yang memiliki arti sama dengan tulisan Bahasa Indonesia. Pada perkembangannya, aksara Sunda tidak lagi hanya berfungsi sebagai media tulis, namun berperan sebagai pendukung karya seni dan kreativitas. Banyak anak muda yang mulai mengukir aksara Sunda pada kaos untuk menambah sisi keindahan. Namun demikian, karena keterbatasan penguasaan terhadap cara mengukir hurufnya, dalam beberapa papan nama jalan dan baliho yang terpajang melintang di tengah masyarakat masih terdapat kesalahan dalam penulisan aksara Sunda, sehingga bila dibaca akan menghasilkan ejaan yang berbeda (Sopian, Ruhimat dan Pradana, 2017).

Keahlian menguasai aksara Sunda perlu dilestarikan agar kebenaran cara menulisnya dapat dipertahankan. Hal ini disebabkan saat ini telah terjadi kekeliruan cara mengukir huruf Sunda, terlebih kesalahan tersebut ada pada papan nama jalan yang notabene dilihat oleh mata publik, seperti yang terjadi pada tulisan papan nama jalan di Kota Bandung. Pada surat kabar lokal Tribun Jabar (2016) versi online dijelaskan bahwa kesalahan pengukiran Jalan Sukarno, Jalan Hanoman, Jalan Kebon Jukut, Jalan Lengkong Kecil, Jalan Lengkong Besar dan Jalan Inggit Ganarsih. Jika 
dibaca, tulisan aksara Sunda yang salah ukir pada nama tersebut menjadi Soekaarano, Nyala Hoang, Jala Jukuta, Jala Lenagakonaga Kecila, Nyla LengngaA Ongnga E Arad dan Jala Inagagita Gaamaasiha.

\section{SIMPULAN}

Pada Museum Sri Baduga terdapat berbagai koleksi yang mengandung pengetahuan lokal Sunda, seperti keahlian membuat batik dan tenun, menguasai peralatan dan cara nenanam tumbuhan atau menangkap ikan sebagai mata pencaharian, mendesain kampung, menciptakan alat penerangan, terampil dalam kerajinan dan gerabah, industri pande besi, perhitungan kalender tradisional, kesenian, kelihaian tentang permainan tradisional, hingga penguasaan bahasa dan ukiran aksara. Pada masing-masing klasifikasi koleksi terdapat pengetahuan masyarakat tentang pilihan jenis bahan sebelum menjadi produk, kegunaan, hingga makna falsafah yang tersimpan dibalik koleksi tersebut. Variasi benda yang dibuat oleh masyarakat terus mengalami perkembangan (bentuk artefak maupun nilai moralnya) seiring dengan proses transfer pengetahuan dari generasi ke generasi. Susunan latar dan patung dalam diorama di museum memudahkan siapa saja mengetahui cara pembuatan produk secara tradisional. Koleksi di museum menjadi bukti keragaman pengetahuan sekaligus keluhuran budi budaya Sunda selama berabad-abad.

\section{DAFTAR PUSTAKA}

Abdussalam, M. S. (2016). Sukarno Jadi Soekaarano, Satu Contoh Calah Papan Nama Jalan Beraksara Sunda. Diunduh dari https://jabar.tribunnews.com/2016/01/26/sukarno-jadisoekaarano-satu-contoh-salah-papan-nama-jalan-beraksara-sunda

Dinas Pariwisata dan Kebudayaan - Pemerintah Daerah Provinsi Jawa Barat. (2019). Museum Sri Baduga Membagi Semua Koleksi Yang Ada Menjadi 10 Klasifikasi. Diunduh dari http://www.uptdkebudayaan.jabarprov.go.id/koleksi

Denzin, N. K. dan Lincoln, Y. S. (2009). Handbook of qualitative research. Yogyakarta: Pustaka Pelajar.

Indrawardana, I. (2012). Kearifan Lokal Adat Masyarakat Sunda dalam Hubungan Dengan Lingkungan Alam. Komunitas, 4, 1, 1-8. DOI: 10.15294/komunitas.v4il.2390

Ipa, M., Prasetyo, D. A., Arifin, J. dan Kasnodihardjo. (2014). Balutan Pikukuh Persalinan Baduy: Etnik Baduy dalam-Kabupaten Lebak. Diunduh dari www.pusat4.litbang.depkes.go.id > buku > pikukuh

Jubaedah, R. S. (2018). Ternyata kalender Sunda ada tiga jenis, berbeda dengan Pabaru Sunda. Tribun Jabar. Diunduh dari https://jabar.tribunnews.com/2018/08/23/ternyata-kalendersunda-ada-tiga-jenis-berbeda-dengan-pabaru-sunda

Nugraha, A. (2015). Angklung tradisional Sunda: Intangible, cultural heritage of humanity, penerapannya dan pengkontribusiannya terhadap kelahiran angklung Indonesia. Jurnal awi laras, 2, 1, 1-23. https://osf.io > download > format=pdf

Okorafor, C. N. (2010). Challenges confronting libraries in documentation and communication of indigenous knowledge in Nigeria. The International Information \& Library Review, 42, 813. doi:10.1016/j.iilr.2010.01.005 
Pemerintah Kota Bogor. (2019). Kampanye Astaga, Ridwan Kamil jajal permainan tradisional Sunda bersama anak sekolah. Diunduh dari https://kotabogor.go.id/index.php/show_post/detail/13239

Saleh, F., Soejadi dan Lasiyo. (2013). Makna "Silas" menurut kearifan budaya Sunda perspektif filsafat nilai: relevansinya bagi pemberdayaan masyarakat miskin. Sosiohumaniora: Journal of Social Sciences and Humanities, Vol. 15, 2. DOI 10.24198/sosiohumaniora.v15i2.5745

Soh, M. B. C. and Omar, S. K. (2012). Small is big: The charm of indigenous knowledge for sustainable livelihood. Procedia-Social and Behavioral Sciences, 36, 602-610. doi: 10.1016/j.sbspro.2012.03.066

Sopian, R., Ruhimat, M. dan Pradana, A. (2017). Rekonstruksi font aksara Sunda unicode sebuah alternatif perbaikan font aksara Sunda. Metahumaniora: Jurnal Bahasa, Sastra dan Budaya, 7, 1, 42-54. 10.24198/mh.v7i1.23327

Sofyan, A. N., Sofianto, K., Sutirman, M. dan Suganda, D. (2018). Eksistensi dan Regenerasi Kerajinan Tangan Anyaman Bambu di Tasikmalaya. Metahumaniora: Jurnal Bahasa, Sastra dan Budaya, 8, 1, 90-99. DOI 10.24198/mh.v8i1.18877

Sunarya, Y. Y. (2018). Adaptasi unsur estetik Sunda pada wujud ragam hias batik Sunda. J. Vis. Art \& Des, 10, 1, 27-51. DOI: 10.5614/j.vad.2018.10.1.3

Suparman, T., Wagiati., Darmayanti, N. dan Wahyu. (2018). Nama permainan tradisional Sunda di Kecamatan Ibun Kabupaten Bandung: Suatu Kajian Geolinguistik. Metahumaniora: Jurnal Bahasa, Sastra dan Budaya, 8, 1, 29-38. DOI: 10.24198/mh.v8i1.18872

Supriadin, J. (2019). Perajin Pande Besi Garut Riwayatmu Kini. Diunduh dari https://www.liputan6.com/regional/read/3993225/perajin-pandai-besi-garut-riwayatmu-kini

Warren, E. and Matthew, G. (2018). Public libraries, museums and physical convergence: Context, issues, opportunities: A literature review Part 1. Journal of Librarianship and Information Science. DOI: 10.1177/0961000618769720

Wiradimadja, A. (2018). Kearifan lokal masyarakat Kampung Naga sebagai konservasi alam dalam menjaga budaya Sunda. Jurnal Sosiologi Pendidikan Humanis. Vol 3, 1, 1-8. http://journal2.um.ac.id/index.php/jsph/article/view/3655 